\title{
Analisis Tradisi Melemang dalam Kajian Etnomatematika Dan Penerapannya dalam Pembelajaran Matematika
}

\author{
Wahyu Fitroh \\ SMP Negeri 7 Muaro Jambi Provinsi Jambi \\ Corresponding email: fitrohwahyu271@gmail.com
}

\begin{abstract}
The understanding of values in mathematics learning delivered by the teachers has not touched all possible aspects. Mathematics is seen as a tool to solve practical problems in the world of science alone, thus ignoring the view of mathematics as a human activity (Soedjadi, 2007). That view is not wrong at all, both are correct and in accordance with the growth of mathematics itself. However, due to or the impact of routine mathematics teaching so far, the view that states mathematics solely as a tool becomes inappropriate in the process of education of the nation's children. It often happens that the teacher places more emphasis on teaching the tool, the teacher tells or shows the tool, how the tool is used, how the child learns to use it, without knowing how the tool was made or without criticizing why the tool is used. In fact, not a few teachers are hooked to meet the target of high test scores so that many other values that are far more important for students are forgotten. The process of mathematics education as it is very possible for children to only memorize without understanding, even though they should be able to memorize only after understanding. Based on the description above in this study, the author explains the process of how to make lemang and how to lemang in learning mathematics, so the purpose of this study is to describe and identify mathematics learning in the tradition of melemang kerinci community, namely the community of Three villages (Koto Lolo, Koto Bento, Koto Tengah) Pesisir Bukit Kota Sungai Penuh District. This type of research is a qualitative research with a phenomenological approach that aims to get as complete information as possible about the implementation of ethno-mathematics in mathematics learning. Data collection methods using observation, interviews, and documentation techniques, then analyzed. The results show that in the tradition of melemang there is mathematics learning in the form of: 1. Tube Elements, 2. Tube Nets, 3 . Tube Area, 4. Tube Volume which is part of the material from the Education Unit Level Curriculum (KTSP), School Level First Intermediate (SMP) in class IX Semester I and 5. Social Arithmetic in class VIII Semester I so that it can be concluded that the results of the study show that there is a community tradition of conducting mathematical activities and the application of ethnomatatics as a means to motivate, stimulate students, can overcome boredom and provide new nuances in mathematics learning. This research focuses on only one object sub-study. it is expected that further research will be further developed on other types and cultural traditions of the community and be assessed in order to be more efficient and effective in their discussions (in-depth and directed).
\end{abstract}

Keywords: Melemang Culture; Ethnomatematics; Tubes; Mathematics Learning

\section{PENDAHULUAN}

Menurut Prihastari (2014). Etnomatematik adalah studi matematika yang mempertimbangkan budaya dimana matematika muncul dan merupakan pendekatan yang digunakan `untuk menjelaskan realitas hubungan antara budaya lingkungan dan matematika saat mengajar (Kurumeh, 2004). Jika kita melihat negara-negara lain, keberhasilan negara Jepang dan Tionghoa dalam pembelajaran matematika karena mereka menggunakan etnomatematik dalam pembelajaran matematikanya (Tereziaha, 1999; Obodo, 2000; Kurumeh, 2004; Uloko dan Imoko, 2007). Indikator koneksi matematika yaitu dapat menghubungkan matematika dalam interaksi antara topik matematika, menghubungkan matematika untuk mata pelajaran lain, dan dalam kepentingan dan pengalaman mereka sendiri (NCTM, 2000:4). Koneksi matematika atau koneksi dalam matematika mempelajari pemahaman siswa menghubungkan ide-ide matematika yang akan memfasilitasi kemampuan untuk merumuskan dan memverifikasi dugaan deduktif antara topik.

Sebagaimana observasi yang telah peneliti lakukan pada siswa SMP dalam Kabupaten Muaro Jambi yaitu pelaksanaan pendampingan Kurikulum 2013 tahun 2015 jenjang Sekolah Menegah Pertama (SMP) dengan hasil pengamatan adalah 1 . Kurangnya kemampuan koneksi guru matematika terlihat pada saat penyampaian kosep matematika kepada siswa. 2. Kurangnya kemampuan siswa ini terlihat dari hasil pekerjaan siswa dalam menjawab soal-soal yang diberikan guru yaitu beberapa siswa dapat mengerjakan dengan baik tetapi siswa belum mengkoneksikan soal dengan konsep matematika yang sudah ada. tidak mengkoneksikan antara konsep dengan bidang lain, tidak bisa mengkaitkan soal dengan kehidupan sehari-hari. 3. Hasil observasi menunjukkan menurunnya kecintaan terhadap budaya.4. Kurangnya keterampilan proses siswa dalam pembelajaran dan terlihat belum adanya perangkat pembelajaran yang dapat merangsang peningkatan kemampuan koneksi matematika, karakter cinta budaya lokal siswa dan keterampilan proses. 5. Pembelajaran yang berlangsung tidak merangsang meningkatnya karakter siswa khususnya karakter cinta budaya lokal. 6 . Perangkat pembelajaran yang ada juga lebih fokus pada aspek kognitif saja, sehingga aspek psikomotorik belum dikembangkan seperti keterampilan proses. Mengingat pentingnya koneksi matematika, maka perlu dikembangkannya metode dan strategi pembelajaran yang diterapkan untuk menyampaikan materi ajar 
kepada siswa agar dapat menciptakan iklim kondusif, pengalaman belajar dan meningkatkan kemampuan koneksi siswa.

Berdasarkan hasil studi pendahuluan dan identifikasi pada tradisi melemang masyarakat Kota Sungai penuh yang telah peneliti lakukan dengan tujuan untuk mendeskripsikan dan mengidentifikasi konsepkonsep matematika yang terdapat pada tradisi melemang masyarakat Tiga desa ( Koto Lolo, Koto Bento, Koto Tengah) Kecamatan Pesisir Bukit Kota Sungai Penuh, hasilnya menunjukkan bahwa tradisi melemang merupakan kegiatan menerapkan konsep matematika menggunakan etnomatematika pada materi Tabung Fitroh (2015). Tradisi melemang ini dapat menjadi alternatif pembelajaran matematika di luar kelas serta dijadikan bahan rujukan sebagai pemecahan masalah matematika kontekstual bahwa dimungkinkan untuk dilakukan pencatatan, pendokumentasian dan pembukuan konsep-konsep matematis yang terdapat pada aktivitas melemang masyarakat Kota Sungai Penuh tersebut.

Bishop (1991) dalam (Tandililing, 2013). Matematika yang berkembang dalam lingkungan masyarakat oleh Bishop disebut etnomatematik. Etnomatematika merupakan representasi kompleks dan dinamis yang menggambarkan pengaruh kultural penggunaan matematika dalam aplikasinya. Berpandangan bahwa sekarang ini bidang etnomathematika, yaitu matematika yang timbul dan berkembang dalam masyarakat dan sesuai dengan kebudayaan setempat merupakan pusat proses pembelajaran dan metode pengajaran. Hal ini membuka potensi pedagogis yang mempertimbangkan pengetahuan para siswa yang diperoleh dari belajar di luar kelas.

Kesiapan guru sebagai garda terdepan dalam implementasi kurikulum harus menjadi perhatian penting. Guru adalah seseorang yang berhadapan langsung dengan peserta didik dalam pembelajaran sehingga memberikan pengaruh langsung terhadap keberhasilan peserta didik dalam menyelesaikan tugas pembelajaran, Alawiyah (2014). Namun demikian guru dituntut berperan secara aktif sebagai motivator dan fasilitator pembelajaran sehingga siswa akan menjadi pusat belajar. Hal ini menjadi kendala tersendiri bagi para guru karena tidak semua guru memiliki kompetensi tersebut. Selain itu, guru dituntut kesiapannya untuk melaksanakan kurikulum dalam waktu yang relatif singkat sementara perangkatnya belum disiapkan secara matang. Bukan persoalan yang mudah untuk mempersiapkan guru yang ideal seperti harapan kurikulum 2013 dalam waktu singkat, terutama untuk merubah mindset guru dari yang asalnya hanya bertugas untuk mengajar sementara dalam kurikulum 2013 guru harus mampu mengarahkan siswa untuk aktif, produktif, kreatif dan berpikir kritis.
Budi (2014) Kegiatan pembelajaran sebagaimana diungkapkan diatas adalah suatu kegiatan pembelajaran berpusat pada siswa, persoalan yang kemudian muncul adalah mampukah guru beradaptasi dengan metode pembelajaran yang baru tersebut setelah sekian lama menggunakan metode pembelajaran yang konvensional (ceramah). Pendekatan sebagaimana kurikulum 2013 bukanlah hal baru bagi dunia pendidikan di Indonesia, namun dalam implementasinya masih banyak terjadi kendala.Salah satu kompetensi yang harus di penuhi oleh seorang guru adalah kompetensi pedagogik.

Alasan kedua dilakukan penelitian ini adalah kurikulum yang baru saja disahkan oleh pemerintah adalah kurikulum 2013. Berdasarkan Permendikbud Nomor 81 A Tahun 2013, proses pembelajaran menurut kurikulum 2013 adalah suatu proses pendidikan yang memberikan kesempatan bagi siswa agar dapat mengembangkan segala potensi yang mereka miliki menjadi kemampuan yang semakin lama semakin meningkat dilihat dari aspek sikap (afektif), pengetahuan (kognitif), dan keterampilan (psikomotor). Kemampuan ini akan diperlukan oleh siswa tersebut dalam kehidupannya dan untuk bermasyarakat, berbangsa dan untuk berkontribusi pada kesejahteraan kehidupan umat manusia. Karena itu suatu kegiatan pembelajaran seharusnya mempunyai arah yang menuju pemberdayaan semua potensi siswa agar dapat menjadi kompetensi yang diharapkan. Orientasi kurikulum 2013 adalah terjadinya peningkatan dan keseimbangan antara kompetensi sikap (attitude), keterampilan (skill), dan pengetahuan (knowledge).

Sejalan dengan amanat UU No. 20 Tahun 2003 sebagaimana tersurat dalam penjelasan pasal 35 bahwa kompetensi lulusan merupakan kualifikasi kemampuan lulusan yang mencakup sikap, pengetahuan, dan keterampilan sesuai dengan standar nasional yang telah disepakati, pola pembelajaran yang didalamnya terjadi interaksi dua arah antara guru dan siswa, artinya guru tidak harus selalu menjadi pihak yang lebih dominan. Proses pembelajaran bergeser dari siswa diberi tahu menjadi siswa mencari tahu, dan proses penilaian bergeser dari penilaian berbasis output menjadi berbasis proses dan output (Sholeh Hidayat, 2013). Sudah jelas bahwa dalam kurikulum 2013 siswa diharapkan mampu mencari tahu sendiri tentang materi pembelajaran dengan guru sebagai fasilitator. Sedangkan proses penilaian tidak hanya hasil akhir sebagai satu-satunya pencapaian siswa namun proses untuk mencapai hal tersebut juga digunakan sebagai bahan penilaian. Dalam kurikulum 2013 suatu kegiatan pembelajaran berpusat pada siswa. Persoalan yang kemudian muncul adalah mampukah guru beradaptasi dengan metode pembelajaran yang baru tersebut setelah sekian lama menggunakan metode pembelajaran yang konvensional (ceramah).

Dengan alasan dan pertimbanagan yang telah peneliti paparkan maka peneliti sangat tertarik untuk 
melakukan identifikasi, pengamatan langsung dan menganalisis tradisi melemang masyarakat Kota Sungai Penuh ini dengan tujuan untuk mendeskripsikan dan mengidentifikasi konsep-konsep matematika yang terdapat pada tradisi melemang masyarakat Tiga desa ( Koto Lolo, Koto Bento, Koto Tengah) Kecamatan Pesisir Bukit Kota Sungai Penuh.

\section{METODE}

\section{Jenis Penelitian}

Jenis penelitian ini merupakan penelitian kualitatif. Penelitian ini dilakukan di Kota Sungai Penuh Yaitu di Kecamatan Pesisir Bukit pada Tiga Desa (Koto Lolo, Koto Bento, Koto Tengah ) dipilih 1 orang ibu rumah tangga untuk setiap desa yang mengetahui tentang melemang. Penelitian ini menggunakan pendekatan fenomenologis yang bertujuan untuk mendapatkan informasi selengkap mungkin mengenai implementasi etnomatematika dalam pembelajaran matematika pada tradisi melemang masyarakat di tiga desa tersebut.

Penelitian menggunakan pendekatan kualitatif naturalistik. Alasan penggunaan metode ini karena penelitian ini menekankan pada upaya eksploratif untuk mengkaji secara natural (alamiah) fenomena yang terjadi dan dilakukan pada tradisi melemang. Dalam hal ini penelitian dilakukan untuk mengetahui segala sesuatu yang mungkin terjadi disaat kegiatan melemang dan sebelum kegiatan melemang.

Lokasi yang dipilih untuk melakukan penelitian ini adalah tiga desa (Koto Lolo, Koto Bento, Koto tengah) Kecamatan Pesisir Bukit Kota Sungai Penuh yang merupakan masyarakat yang selalu melaksanakan tradisi melemang secara turun temurun pada saat menyambut puasa dan menyambut hari raya Idul Fitri maupun Idul Adha. Waktu penelitian dilakasanakan pada pertengahan bulan Juli 2014 sampai dengan bulan Desember 2015, karena bertepatan dengan pelaksanaan Ramadhan, Idul Fitri dan Idul Adha tahun $1436 \mathrm{H}$.

\section{Sumber Data}

Informan dalam penelitian ini diambil berdasarkan sampel yang telah ditentukan. Pengambilan sampel berdasarkan Purposive sampling dan snawball sampling. Sugiyono (2007:54) menjelaskan purposive sampling adalah pengambilan data dipilih dengan pertimbangan dan tujuan tertentu biasanya informan yang dianggap mengetahui mengenai tema penelitian yang sedang dikaji. Snow ball sampling adalah Pengambilan data yang awalnya sedikit lama-lama semakin banyak. Informan yang diambil oleh peneliti dalam penelitian ini adalah ibu rumah tangga dan depati ninik mamak dalam masyarakat tiga desa.

\section{Tehnik Pengumpulan Data}

Penelitian ini adalah penelitian kualitatif sumber data dipilih dan disesuikan dengan tujuan penelitian. Proses pengumpulan data mengutamakan perspektif emic (mementingkan bagaimana respoden memandang dan menafsirkan dunia sekitarnya). Sesuai dengan jenis data penelitian ini menggunakan metode pengumpulan data, wawancara, pengamatan dan dokumetasi. Ketiga metode pengumpulan data ini merupakan ciri khas penelitian kualitatif. Metode-metode yang digunakan dalam penelitian ini dapat diuraikan sebagai berikut : Metode ini dilakukan dengan cara mengamati secara langsung tentang kondisi di lapangan, baik yang berupa keadaan fisik maupun perilaku yang terajdi selama berlangsung penelitian. Dalam pengertian sempit observasi berarti pengamatan dan pencatatan secara sistematis terhadap fenomena yang diselidiki. Pengamatan mempunyai maksud bahwa pengumpulan data yang melibatkan iteraksi sosial antara peneliti dengan subyek peneliti maupun informan dalam suatu setting selama pengumpulan data harus dilakukan secara sistematis tanpa menampakan diri sebagai peneliti. Dengan cara seperti ini antara peneliti dan yang diteliti berinteraksi secara timbal balik. Dalam hal ini peneliti memandang yang diteliti bukan subyek atau obyek penelitian tetapi sebagai sebagai responden yang berkedudukan sebagai teman sejawat atau kolega. Mereka beraktivitas, segala sesuatunya tidak dapat ditentukan (undertermine), dan dapat bersama-sama membangun data penelitian.

Analisis data penelelitian dilakukan melalui pendekatan kualitatif. Data yang diperolehdari wawancara mendalam, pengamatan, dokumentasi dan diskusi kelompok terfokusanalisisnya dilakukan secara simultan dengan terlebih dahulu melakukan pemilahan data yangsejenis selanjutnya dilakukan reduksi data, penyajian, dan kesimpulan serta verifikasi. Datadikumpulkan berdasarkan kategori seperti: (1) Bahan dan alat yang digunakan untuk Melemang (2) Langkah-langkah melaksanakan kegiatan melemang (3) Kegiatan melemang yang mengandung unsur matematika (4) Menghubungkan kegiatan melemang dengan pembelajaran matematika.

\section{HASIL DAN PEMBAHASAN}

Berdasarkan temuan penelitian, maka berikut ini dikemukakan beberapa potensi dari melemang di masyarakat tiga desa Koto Lolo, Koto Bento dan Koto Tengah yang dapat dikembangkan dalam pembelajaran matematika.

\section{Memotong Bambu}

Langkah pertama dalam melakukan kegiatan melemang adalah memotong bambu menurut panjang ruas-ruas dari bambu yang dimana setiap potongan ruasnya menjadi buluh yang akan digunakan tempat memasukan ketannya, hasil potongan setiap ruas bambu dengan bagian atas terbuka dan bagian bawah tertutup dengan bukunya yang kemudian disebut buluh dalam kegiatan melemang. Kegiatan ini bahwa hasil penampang potongan dari buluh berupa penampang 
berbentuk dua lingkaran berimpit dengan titik pusat yang sama dimana lingkaran dalam yang merupakan sisi bagian dalam dari buluh yang memiliki jari-jari lebih kecil dari lingkaran luar sebagai batas atau kulit sisi luar buluh, selisih jari jari dua lingkaran berimpit tersebut merupakan ketebalan dari buluh.

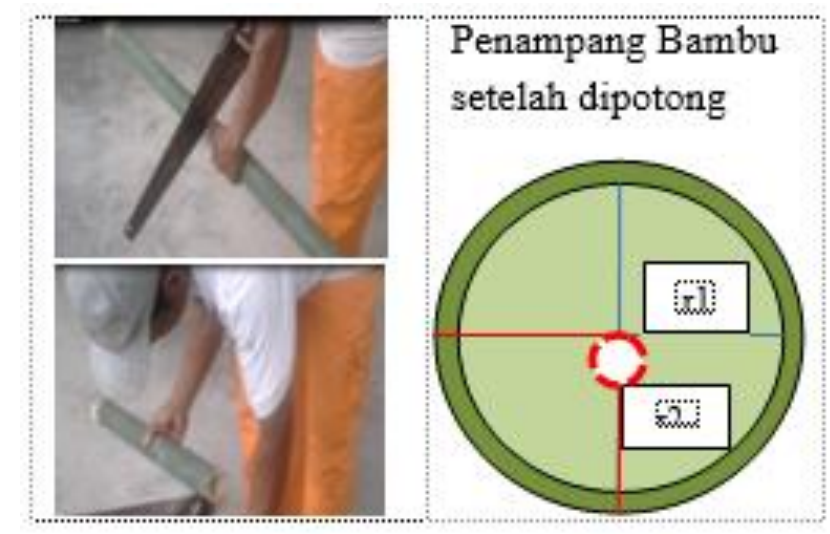

\section{Melapisi buluh dengan daun}

Setelah tersedianya buluh maka perlu digunakan pelapis bagian dalam dari buluh agar lemang tidak lengket pada sisi dalam buluh dengan menggunakan daun pisang.Pada kegiatan ini daun pisang terlebih dahulu dipisahkan dari bagian tegahnya sehingga membentu helai daun pisang kemudian diukur dengan menggunakan buluh yang dilebihkan dari panjang buluh yang tersedia sehingga helai daun pisang ini membentuk persegi panjang.Sebelum helai daun pisai yang berbentuk persegi panjang dimasukan kedalam buluhnya terlabih dahulu dibuat sulur yang berguna sebagai alat memutar daun pisang agar mempermudah memasukan kedalam buluhnya.

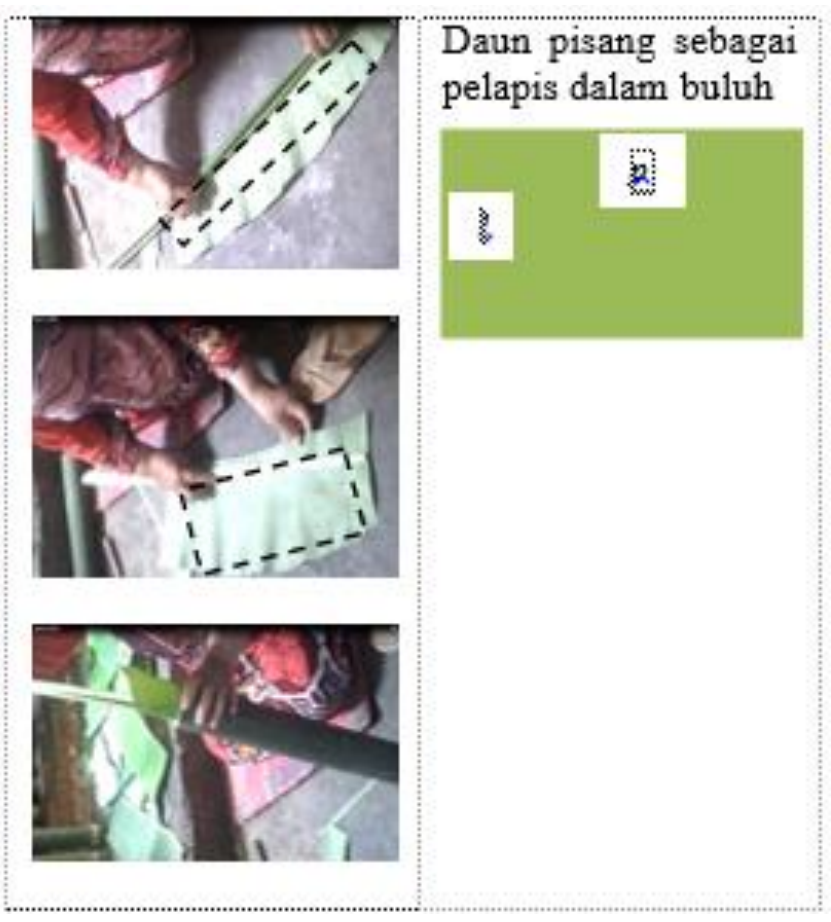

\section{Pengisian ketan kedalam buluh}

Kegiatan selanjutnya adalah memasukan ketan kedalam buluh yang telah dilapisi daun pisang, proses memasukan ketan dilakukan setelah ketan direndamkan dengan air dan dikeringkan supaya lebih lembut dan tidak mengakibatkan pengembangan ketan yang berlebihan, ketan diisikan kedalam buluh sebatas sisi atas buluh kemudian dimasukan santan yang telah diberikan bumbu-bumbu secukupnya. Santan diisi juga sampai memenuhi buluh tapi tidak melewati daun palapis buluh.Pengisian buluh sebagai lemang juga bisa atau sering juga dilakukan dengan mengantikan ketan dengan, pisang, labu sehingga disebut lemang pisang atau lemang labu. Dalam proses memasukan ketan dan santan kedalam buluh sama halnya mengisi sebuah tabung tanpa tutup.

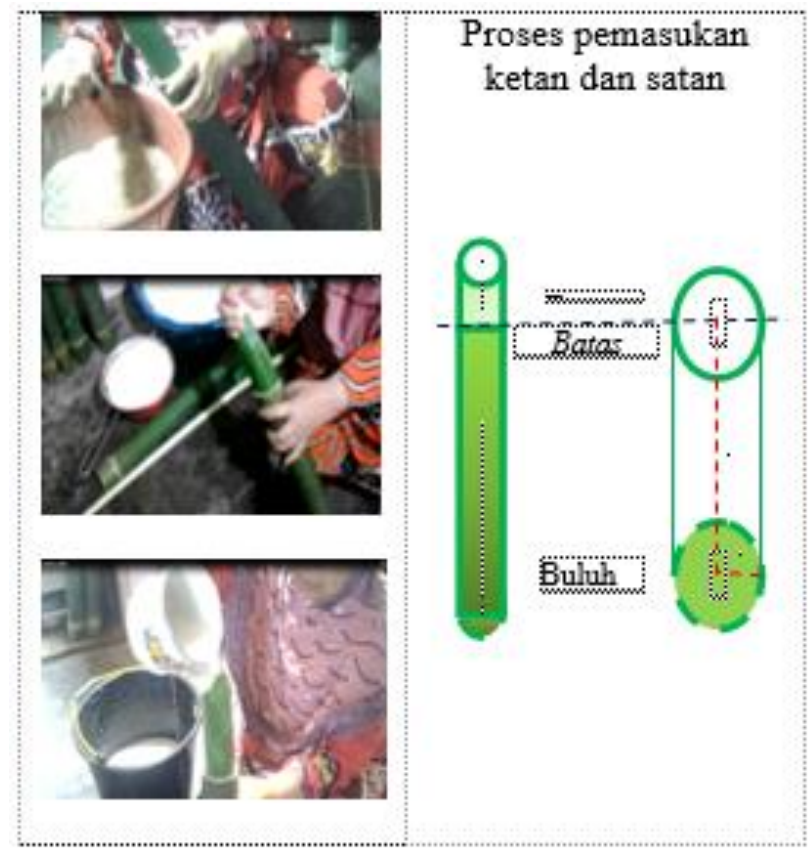

\section{Posisi buluh saat akan dibakar}

Kegiatan selanjutnya pada kegiatan melemang ini adalah proses pembakaran, kegiatan pembakaran didahului dengan membuat dua tiang dengan jarak tergantung dengan jumlah lemang yang akan dibakar pada dua tiang tersebut dihubungkan dengan palang terbuat dari beberapa ruas bambu yang diisi air atu besi hal ini untuk menjaga agar palang tersebut tidak terbakar dengan tinggi sekitar seperempat dari panjang bagian atas buluh lemang tersebut. Buluh yang telah disi dengan ketan dan santan ditegakan miring pada palang tersebut membentuk segitiga siku-siku dimana buluh sebagai sisi miring dan tanah serta tinggi tiang palang sebagai sisisisi penyikunya. Hal ini dilakukan untuk menjaga agar ketan dan santan tidak keluar dari buluhnya. Kedudukan buluh dan palangnya membentuk segitiga siku-siku. 


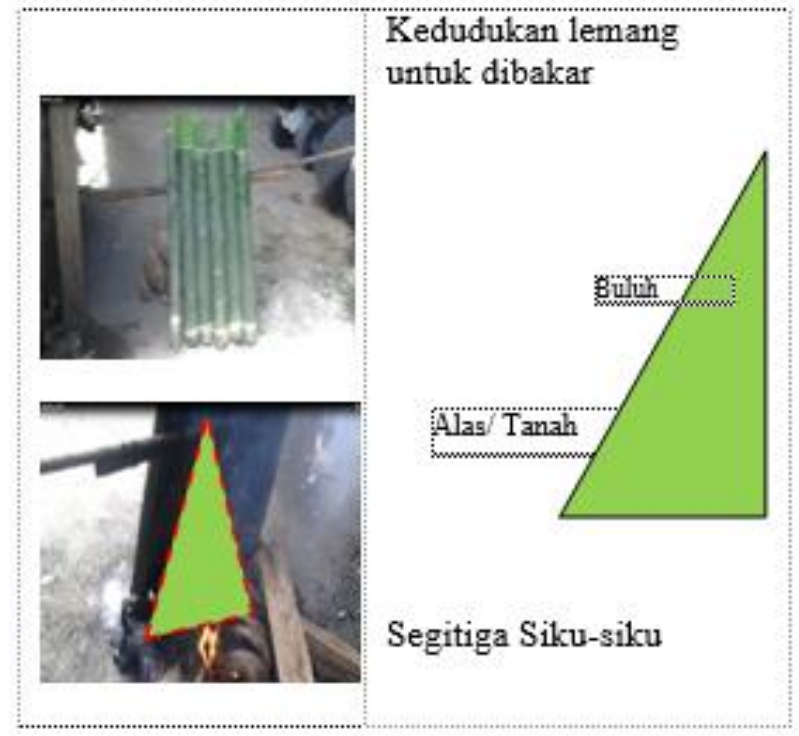

\section{Memasak Lemang}

Proses pembakaran lemang menggunakan dua sampai dua setegah jam dengan tetap memperhatikan kondisi api serta santan agar lemang bisa masak dengan baik, adapun hal yang penting diperhatikan adalah sisi buluh yang menghadap api jangan sampai terbakar sehingga ketan akan masak tidak merata untuk menghidari kejadian tersebut maka disaat bagian sisi buluh yang menghadap api telah berubah warna menjadi kekuningan maka buluh diputar sehingga bagian yang telah berubah warna membelakangi api hal ini dilakukan berulang dengan cara memutar buluh tersebut. Kegiatan memutar buluh disaat melemang ini sesuai dengan materi pelajaran matematika kurikulum 2013 pokok bahasan Transformasi kelas VII semester 2 dengan pokok bahasan memahami konsep transformasi (dilatasi, translasi, pencerminan, rotasi) menggunakan objekobjek geometri.

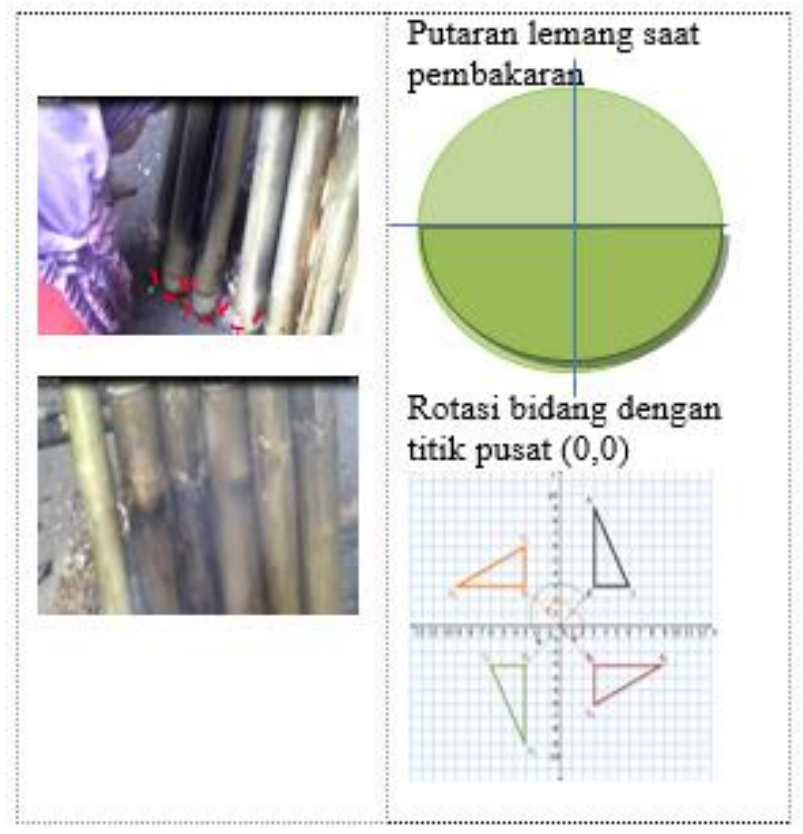

\section{Membuka Lemang}

Setelah proses pembakaran lemang selesai tiba saatnya menikmati hasil dari lemang, hal yang perlu diperhatikan adalah proses mengeluari lemang dari buluhnya yaitu dengan cara membelah lemang dengan menggunakan pisau atau parang diawali dengan membelah lemang dari sisi atas lemang tetapi tidak sampai parang menembus sisi bawah lemang melainkan hanya bagian atas lemang kemudian membelah dengan menggunakan tangan sehingga sebagian dari buluh terlepas atau dengan kata lain membelah buluh menjadi dua bagian membentuk setegah tabung tanpa tutup, sehingga sebagian dari buluhnya memuat lemangnya dan sebagiannya terlepas dari lemangnya. Proses kegiatan diatas dapat dihubungkan dengan pelajaran matematika kurikulum 2013 pokok bahasan luas dan volume pada kelas IX semester 2 dengan kompetensi dasar menentukan luas selimut dan volume tabung, kerucut, dan bola dan menaksir dan mengitung luas permukaan bangun datar dan bangun ruang yang tidak beraturan dengan menerapkan kombinasi geometri dasar.

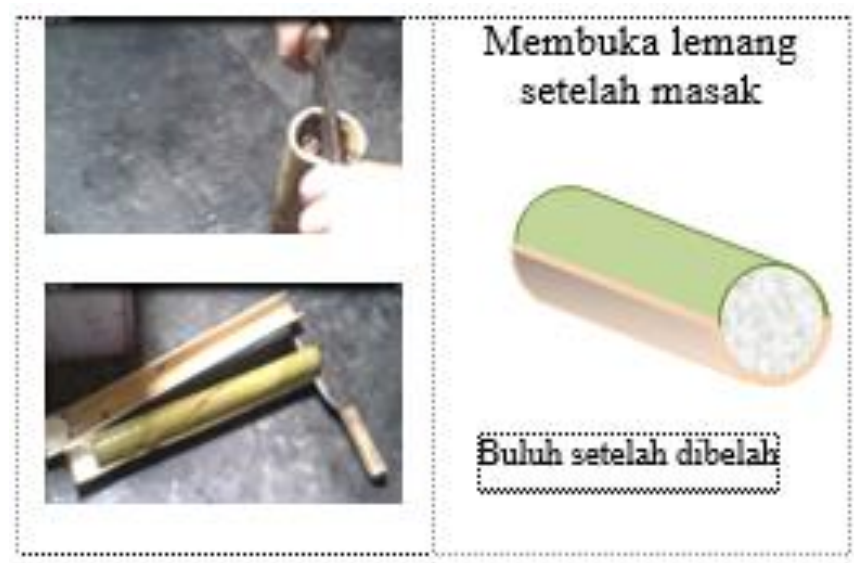

\section{Menghidangkan Lemang}

Kegiatan terakhir adalah menghidangkan lemang, setelah buluh terbagi dua maka kita dapat melihat lemang secara utuh maka bagian buluh yang berisi lemang tidak langsung dilepaskan sebagai alas untuk memotong lemang sesuai dengan keinginan, proses memotong ini merupakan pelajaran matematika pada pokok bahasan perbandingan pada kelas IX semester 1 kurikulum 2013 pada kompetensi dasar menggunakan konsep perbandingan untuk menyelesaikan masalah nyata mencakup perbandingan bertingkat dan persentase dengan menggunakan tabel, grafik, dan persamaan serta pelajaran matematika kelas VII semester 2 pokok bahasan perbandingan dan kompetensi dasar memahami konsep perbandingan dan menggunakan bahasa perbandingan dalam mendeskripsikan hubungan dua besaran. 


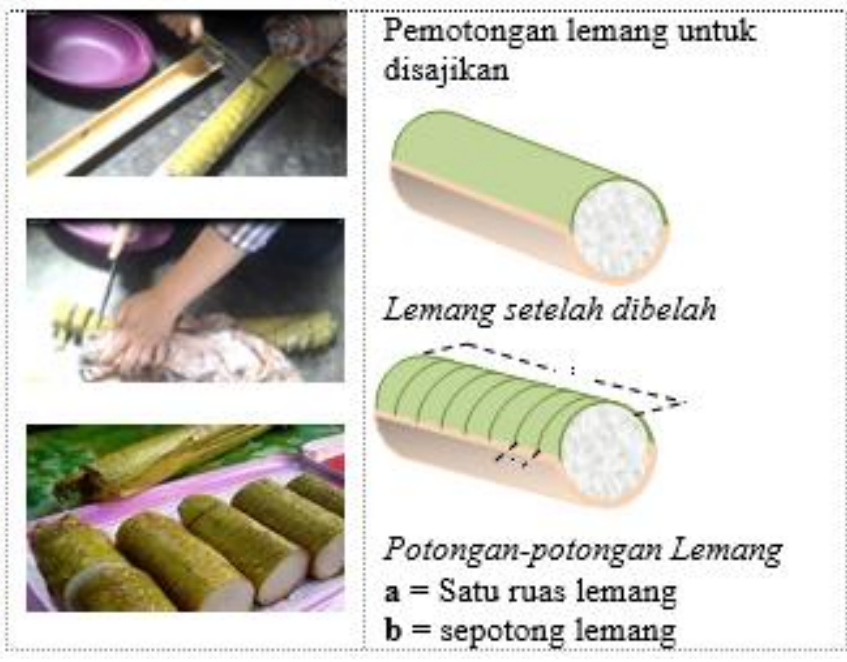

Dari hasil paparan diatas disimpulkan potensi melemang masyarakat tiga desa kecamatan Pesisir Bukit Kota Sungai Penuh yang dapat dikembangkan dalam pembelajaran matematika adalah kegiatan pemotongan buluh dimana penampang buluh hasil potongan adalah berupa lingkaran dalam dan lingkaran luar dimana selisih jari-jari dua lingkaran merupakan ketebalan dari buluh yang digunakan untuk melemang, daun pisang yang digunakan untuk melepisi bagian dalam dari buluh merupakan bangun datar persegi panjang yang juga dapat merupakan jarring-jaring dari tabung, proses pengisian ketan dan santan kedalam buluh yang merupakan menentukan volume dari sebuah tabung terbuka, kegiatan meletakan lemang pada palang dan dua tiang membentuk bangun datar segitiga, pembakaran lemang yang diputar untuk menjaga agar lemang dapat masak dengan baik adalah merupakan taransformasi berupa rotasi, pengeluaran lemang dari buluh setelah masak adalah merupakan volum dari tabung serta penyajian atau menghidang lemang merupakan pembelajaran perbandingan dalam pelajaran matematika.

Dengan demikian matematika seseorang dipengaruhi oleh latar budayanya, karena yang mereka lakukan berdasarkan apa yang mereka lihat dan rasakan. Budaya akan mempengaruhi perilaku individu dan mempunyai peran yang besar pada perkembangan pemahaman individual, termasuk pembelajaran matematika (Bishop, 1991).

Penerapakan etnomatematika sebagai suatu pendekatan pembelajaran akan sangat memungkinkan suatu materi yang pelajari terkait dengan budaya mereka sehingga pemahaman suatu materi oleh siswa menjadi lebih mudah karena materi tersebut terkait langsung dengan budaya meraka yang merupakan aktivitas mereka sehari-hari dalam bermasyarakat. Tentunya hal ini membantu guru sebagai fasilitator dalam pembelajaran untuk dapat memfasilitasi siswa secara baik dalam memahami suatu materi. (Wahyuni dkk: 2013).

\section{Pembahasan}

Pada kegiatan tradisi melemang masyarakat tiga desa (Koto Lolo, Koto Bento, Koto Tengah) kecamatan Pesisir Bukit Kota Sungai Penuh sebagaimana Bishop (1991) mengungkapkan konsepsi hitungan matematika yang lebih luas menggambarkan bahwa matematika berdasarkan pada kebudayaan akan membangkitkan pengetahuan matematika untuk menyesuaikan dengan sasaran dan tujuan komunitas yang diharapkan dapat menyelesaikan masalah dan untuk menentukan aturan dalam kehidupannya.

Sejalan dengan paham konstruktivis (Sutrisno, 1995) bahwa pengetahuan seseorang dibangun melalui pengalaman yang ada dilingkungannya, sehingga apabila guru mengajar di dalam kelas mengaitkan pengalaman siswa di lingkungannya dengan materi pelajaran yang akan dibahas maka siswa dapat memahami makna pembelajaran. Dengan demikian etnomatematika sebagai "jembatan kearah matematika formal/matematika sekolah.

Kegiatan masyarakat untuk melemang tersebut rutin dilakukan setiap acara-acara adat, menyambut bulan puasa, menyambut lebaran idul fitri serta menyambut lebaran idul adha. Kegiatan-kegiatan dalam tradisi melemang yang mengandung unsur matematika sebagai berikut: (1) Kegiatan memotong bambu sebagai buluh untuk melemang. Materi lingkaran merupakan bagian dari geometri yang masih sulit dipahami oleh siswa, sehingga perlu ada terobosan baru agar menjadi mudah diterima siswa.Bangun - bangun abstrak seperti lingkaran perlu dijelaskan dengan benda-benda konkrit untuk itu perlu diupayakan alternatif pendekatan pembelajaran matematika yang lebih bervariasi dan mengena pada sasaran.

Hal ini sejalan dengan model pembelajaran penemuan terbimbing yaitu metode penemuan yang dipandu oleh guru, guru membimbing siswa jika diperlukan dan siswa didorong untuk berpikir sehingga dapat menemukan prinsip umum berdasarkan bahan yang disediakan oleh guru (Markaban, 2006: 15). (2) Kegiatan melapisi buluh dengan daun.Menurut Nani Sumarni (dalam Soemadi, 1994) agar dapat belajar geometri dengan baik dan benar, siswa dituntut untuk menguasai kemampuan dasar geometri, keterampilan dalam pembuktian, keterampilan membuat lukisan dasar geometri, dan mempunyai pandangan bentuk abstrak yang memadai.Menurut Sudjana (2005: 179) dalam (Sidiq, 2015), proses pembelajaran khususnya pembelajaran matematika akan lebih efektif dan bermakna apabila siswa berpartisipasi aktif. Salah satu ciri kebermaknaan dalam proses belajar mengajar adalah adanya keterlibatan atau partisipasi siswa dalam proses belajar mengajar.

Sedangkan menurut (Bobango, 1993: 148) dalam (Susanto dkk) tujuan pembelajaran geometri adalah agar siswa memperoleh rasa percaya diri mengenai kemampuan matematikanya, menjadi pemecah masalah 
yang baik, dapat berkomunikasi secara matematik, dan dapat bernalar secara matematik. Pada dasarnya geometri mempunyai peluang yang lebih besar untuk dipahami oleh siswa dibandingkan dengan cabang matematika yang lain. Hal ini dikarenakan objek geometri seperti garis, bidang dan ruang merupakan hal yang mudah untuk diwujudkan secara konkret dalam kehidupan sehari-hari baik sebelum mereka sekolah maupun sewaktu mereka sekolah.(3) Kegiatan Pengisian buluh dengan ketan dan santan.

Menurut Nurhayati (2014) mengatakan bangun ruang adalah sejenis benda ruang beraturan yang memiliki rusuk, sisi dan titik sudut dengan demikian buluh dapat dikatakan sebagai bangun ruang tabung tanpa tutup.Hal ini dapat memberikan kesempatan kepada siswa untuk bertukar pendapat, menanggapi pemikiran siswa yang lain, menggunakan media yang ada, akan dapat mengingat lebih lama mengenai suatu fakta, prosedur, definisi dan teori dalam matematika dan memberikan pengalaman belajar yang tidak sematamata hanya pengalaman belajar matematika. Selain mengkonkritkan konsep yang terdapat di dalam pembelajaran, media buluh sebagai bangun ruang tabung juga dapat mempermudah siswa dalam menerima materi tentang sifat-sifat bangun ruang. Sebagaimana Hiebert \& Capenter (1992) mengingatkan kepada semua pihak bahwa pengajaran matematika di sekolah dan matematika yang ditemukan anak dikehidupan seharihari sangat berbeda, hal tersebut diduga sebagai penyebab sulitnya siswa mempelajari matematika.

Oleh sebab itu menurut hasil penelitian Tandililing (2013) dikatakan bahwa pembelajaran matematika sangat perlu memberikan muatan/menjembatani antara matematika dalam dunia sehari-hari yang berbasis pada budaya lokal dengan matematika sekolah. (4) Kedudukan lemang saat pembakaran. Harni Suparsih dalam (Suparno, 1997: 6162), belajar merupakan 1. Proses aktif pelajar mengkonstruksi arti antara teks, dialog, pengalaman dan lain-lain, 2. Proses mengasimilasikan dan menghubungkan pengalaman atau bahan yang dipelajari dengan pengertian yang sudah dipunyai seseorang sehingga penegertiannya dikembangkan, dan 3. Suatu proses pemikiran dengan membuat kerangka pengertian yang berbeda. Pada dasarnya siswa perlu melakukan upaya-upaya yang dapat mengali atau memacu perilaku kreatif. Perilaku kreatif tersebut dapat menggali atau kemampuan untuk menghasilkan/ mengemukakan, merespons, mewujudkan ide dan menanggapai masalah (Nursisto: 2000).(5) Kegiatan saat memasak lemang. Yuhasriati (2012) mengatakan pembelajaran harus memberikan kesempatan siswa untuk reinvent (menemukan/ menciptakan) matematika melalui praktek (doing it). Belajar sambil melakukan aktifitas (learning by doing) pengalaman belajar yang didapat oleh siswa lebih tahan lama tersimpan dalam benak siswa.
Hal ini sangat relevan dengan pembelajaran matematika yang dikembangkan oleh Freudenthal (dalam Suryanto, 2000:110) yang menurutnya, matematika harus dihubungkan dengan kenyataan, berada dekat dengan siswa dan relevan dengan kehidupan masyarakat agar memiliki nilai manusiawi. Ellis dan Foults (2000:2) mengemukakan bahwa pembelajaran kelompok dapat meningkatkan hasil belajar dengan menerapkan model-model tertentu dalam pembentukannya. Sehingga tercipta pola interaksi tertentu diantara anggota kelompok. Salah satunya dengan Problem Based Learning. (6) Kegiatan membuka lemang setelah dimasak. Menurut Simangungsong S.W (2008), tabung merupakan bangun ruang sisi lengkung yang alas serta tutupnya berupa lingkaran dengan panjang jari-jari sebesar $r$, jarak antara pusat alas dan pusat pusat tutup disebut tinggi (t).Seiring dengan pendapat Sari, D. P (2014) suasana menyenangkan dapat tercipta saat terlaksananya pendekatan scientific. Siswa awalnya terbiasa dengan buku pelajaran yang ditawarkan guru dan hanya terpaku pada masalah dalam buku tersebut. (7) Kegiatan menghidang lemang. Hal ini sebagaimana diungkapkan bahwa pembelajaran matematika dapat dilakukan salah satunya dengan mengembangkan pengetahuan dasar etnomatematika siswa menjadi salah satu alternatif pembelajaran matematika di luar kelas melalui bentuk permainan tradisional (Rachmawati: 2013). Menurut Nurfarikhin. F (2010) kemampuan pemecahan masalah bagi peserta didik sangat penting dan sangat diperlukan karena dapat digunakan atau dimanfaatkan para peserta didik ketika mereka terjun langsung di masyarakat. Namun konsep dalam matematika adalah ide abstrak yang memungkinkan kita untuk mengelompokkan dan mengklasifikasikan objek atau kejadian.Suatu konsep biasa dibatasi dalam suatu ungkapan yang disebut definisi (Wardani, 2000: 85).

Dari uraian di atas penulis berpendapat bahwa kegiatan belajar perlu menciptakan lingkungan belajar yang dapat merangsang keaktifan siswa serta meningkatkan keterampilan proses dengan cara membentuk kelompok belajar diskusi, yang hetrogen. Dengan berdiskusi siswa diberikan keleluasaan untuk bertanya. Sesuai dengan pendapat Suseno dalam (Suharta, 2000) belajar bertanya (posing) sangat penting dalam proses pendidikan. Bertanya sebagai awal usaha intelektual yang berfungsi untuk merangsang pikiran, mendobrak wawasan yang kaku dan sempit, membuka cakrawala dan mencerdaskan. Untuk itu diperlukan strategi pembelajaran yang dapat membantu siswa untuk mencapai kompetensi dasar dan indikator pembelajaran.

\section{SIMPULAN}

Berdasarkan hasil-hasil penelitian dan pembahasan yang telah dipaparkan sebelumnya, dapat ditarik kesimpulan berikut ini: 1. Berbagai proses kegiatan melemang masyarakat tiga desa (Koto Lolo, 
Koto Bento, Koto Tengah) Kecamatan Pesisir Bukit Kota Sungai Penuh mempunyai nilai Etnomatematika. Gagasan Etnomatematika yang dipraktikkan dalam masyarakat ini dapat memperkaya pengetahuan matematika yang telah ada. 2. Bentuk aktivitas melemang masyarakat masyarakat tiga desa (Koto Lolo, Koto Bento, Koto Tengah) Kecamatan Pesisir Bukit Kota Sungai Penuh yang bernuansa matematika yang bersifat bangun datar, bangun ruang, trasformasi dan perbandingan yang dipraktikkan dan berkembang dalam aktivitas melemang mempunyai nilai matematika yang dapat dikembangkan dalam pembelajaran pada beberapa materi pelajaran matematika Sekoalah Dasar (SD) maupun Sekolah Menegah Pertama (SMP) 3. Representasi eksternal meliputi proses dalam aktivitas melemang mulai dari memilih buluh sampai pengindangankan lemang merupakan gagasan matematika. 4. Berbagai potensi dari etnomatika yang dipraktikkan masyarakat masyarakat tiga desa (Koto Lolo, Koto Bento, Koto Tengah) Kecamatan Pesisir Bukit Kota Sungai Penuh dapat dikembangkan dalam berbagai pokok bahasan atau materi matematika di Sekolah Dasar maupun Sekolah Menegah Pertama seperti pada materi bangun datar segi empat, bangun datar lingkaran, bangun ruang tabung dan perbandingkan.

\section{Saran}

Berdasarkan kesimpulan penelitian dapat diajukan saran-saran berikut ini:

1. Perlunya peningkatan penelaah secara mendalam etnomatematika yang dipraktikkan masyarakat atau etnis tertentu agar untuk menjembatani matematika yang dipraktikkan di masyarakat dengan matematika yang dipelajari di sekolah khususnya Sekolah. Mengingat etnis masyarakat tiga desa (Koto Lolo, Koto Bento, Koto Tengah) Kecamatan Pesisir Bukit yang ada di Kota Sungai Penuh begitu banyak, maka penelaah etnomatematika pada sub masyarakat lainnya perlu menelaan secara khusus.

2. Bagi perancang kurikulum, dalam merencanakan dan menyusun kurikulum muatan lokal diharapkan mampu membaca kebutuhan daerah dan kebutuhan sekolah dimana lembaga tersebut berada.

3. Mencermati etnomatematika sebagai materi alternatif atau sebagai jembatan ke matematika formal sebagai perpaduan dalam pembelajaran matematika, maka para guru perlu diberi perbekalan dan penyadaran yang memadai sebab materi etnomatematika di samping sebagai muatan lokal juga untuk mengaplikasikan budaya masyarakat yang hampir punah akibat arus modernisasi.

4. Memang perlu diakui adanya kesulitan memasukkan etnomatematika ke sekolah dengan sistem pendidikan yang terpusat seperti di negara kita. Hal ini disebabkan kerena buku-buku teks dan sumber belajar lainnya telah dikemas dengan rapih dan kaku untuk itu cara terbaik adalah melalui kreativitas para guru untuk menyeleksi dan menjabarkan kurikulum yang ada.

\section{DAFTAR PUSTAKA}

Agung Hartoyo (2012): Eksplorasi Etnomatematika pada budaya Masyarakat Dayak Perbatasan IndonesiaMalaysia Kabupaten Sanggau Kalbar. Jurnal Penelitian Pendidikan. 13(1). Hlm. 14-23. (http://jurnal.upi.edu)

Alawiyah F. (2014): Kesiapan guru dalam implementasi kurikulum 2013, Info Singkat Kesejahteraan Sosial, kajian Singkat terhadap isu-isu terkini, vol. VI, no. 15/i/p3di/agustus/2014

Anita Dewi Utami dkk (2014): Strategi Guru Dalam Membelajarkan Matematika Pada Materi Lingkaran Kepada Anak Tunagrahita (Studi Kasus pada Siswa Kelas VIII SLB Muhammadiyah Cepu). Program Pascasarjana Pendidikan Matematika Universitas Sebelas Maret. Jurnal Elektronik Pembelajaran Matematika. ISSN: 2339-1685 Vol.2, No.8, hal 853-864, Oktober 2014, http://jurnal.fkip.uns.ac.id

Budi Bangun S. (2014): Jurnal Strategi guru dalam menghadapi kurikulum 2013 di SMA Negeri 2. Fakultas Keguruan dan Ilmu Pendidikan Universitas Sebelas Maret Surakarta.

Fitroh Wahyu. 2015. Inditifikasi tradisi melemang pada masyarakat Kerinci pada materi tabung. Jurnal Seminar Nasional UMS Surakarta.

Fitri.A, (2010) Etnomatematika Menambah nilai Pendekatan Matematika, Profesor Dr. Shaharir Mohamad Zain.http://shaharirbrmz.blogspot.com

Hartoyo, Agung. (2012): Eksplorasi Etnomatematika Pada Budaya Masyarakat Dayak Perbatasan Indonesia-Malaysia Kabupaten Sanggau Kalbar, Jurnal Penelitian Pendidikan, Vol. 13 No. 1.

Harni Suparsih (2006): Meningkatkan aktifitas belajar siswa pada pembelajaran geometri ruang melalui pemamfaatan portofolio di Sekolah Atas Program pascasarjana program studi pendidikan matematika Universitas Negeri Semarang.

Hanafi. RM, (2014): Aplikasi Borobudur Ethnomatematics, Media Pembelajaran Matematika sebagai Pendukung Pembelajaran Geometri Berbasis Etnomatematika. Universitas Negeri Yogyakarta, email: pru.ridzqihanafi@gmail.com

Hastuti. N. L (2014): Berkenalan Dan Berdampingan Dengan Etnomatematika Dalam Pendidikan Di Indonesia Prodi Pendidikan Matematika, FMIPA, UNY.http://Nuraidalutfi.Blogspot.Co.Id/2014/03/ Berkenalan-Dan-Berdampingan-Dengan.Html

Inayatul Hidayah (2011): Pengaruh pembelajaran matematika dengan pendekatan keterampilan proses terhadap kemampuan pemecahan masalah materi pokok lingkaran kelas VIII MTsN Nurul 
Huda Semarang tahun pelajaran 2010/2011 Fakultas tarbiyah Institut Agama Islam Negeri Walisongo Semarang

Diah Prawitha Sari (2014): IJCETS 3 (1), Pendekatan Scientific Berbasis Ict Untuk Mengembangkan Kemampuan Berpikir Matematik, 33-38. Program Studi Pendidikan Matematika Pascasarjana Universitas Pendidikan Indonesia.Indonesian Journal of Curriculum and Educational Technology Studies http://journal.unnes.ac.id/sju/index.php/jktp 33-38.

Nurhayati (2014): Peningkatan Hasil Belajar Siswa Menggunakan Model Bangun Ruang Dalam Pembelajaran Matematika Di Sekolah Dasar Artikel Penelitian Program Studi Pendidikan Guru Sekolah Dasar Jurusan Pendidikan Dasar Fakultas Keguruan Dan Ilmu Pendidikan Universitas Tanjungpura Pontianak

Nurfarikhin, Fuad (2010): Hubungan Kemampuan Pemahaman Konsep Dan Kemampuan Penalaran Dengan Kemampuan Pemecahan Masalah Pada Materi Bangun Ruang Sisi Lengkung Peserta Didik Kelas IX Mts Nu 24 Darul Ulum Pidodo Kulon Patebon Kendal Program studi Pendidikan Islam dalam Ilmu Pendidikan Matematika Fakultas Tarbiyah Institut Agama Islam Negeri Walisongo Semarang.

NCATE/NCTM (2003).Programs for Initial Preparation of Mathematics Teachers.http://www.math.uri.edu/ eaton/NCATE NCTM.pdf

NCTM (2000): Executive Summary Principles and Standards for School Mathematics.http://www.nctm.org/uploadedFiles/ Math_Standards/12752_exec_pssm.pdf

Prihastari. E.B, Pemanfaatan Etnomatematik Melalui Permainan Engklek Sebagai Sumber Belajar .Email: (butsinegara@gmail.com) Program Studi Pendidikan Guru Sekolah Dasar Universitas Slamet Riyadi.

Rachmawati Inda (2012): Eksplorasi Etnomatematika Masyarakat Sidoarjo, MATHEdunesa, Vol 1 Nomer 1.si_inda_rachmawati@yahoo.com.

Rochmad (2012): Desain Model Pengembangan Perangkat Pembelajaran Matematika. Jurnal Kreano, Volume 3 (1), 59-72.

Ro'iyatunisa. A (2014): Peranan Guru Dalam Implementasi Kurikulum 2013

Rizka S. dkk UJMER 3 (2) (2014) Model Project Based Learning Bermuatan Etnomatematika Untuk Meningkatkan Kemampuan Koneksi Matematika Program Studi Matematika, Program Pascasarjana, Universitas Negeri Semarang, Unnes Journal of Mathematics Education Research (http://journal.unnes.ac.id/sju/index.php/Ujmer).
Setiana Dafid S. (2016): Pengembangan Etnomatematika Berorientasi Learning Trajectory Program Studi Ilmu Pendidikan Program Pascasarjana Universitas Negeri Yogyakarta.

Sepdoni. R (2013), Pembelajaran Problem Based Learning (Pbl) Untuk Meningkatkan Prestasi Belajar Siswa Kelas VIII-E Smp Negeri 3 Malinau Barat Pada Materi Garis Singgung Lingkaran.Artikel Universitas Negeri Malang Fakultas Matematika Dan Ilmu Pengetahuan Alam Jurusan Matematika Program Studi Pendidikan Matematika.

Soedjadi. R, (2000), Kiat Pembelajaran Matematika di Indonesia, (Jakarta: Diretoral Jendral Pendidikan Tinggi, Departemen Pendidikan Nasional, 1999/2000), hlm. 43.

Supriadi (2010): Pembelajaran Etnomatematika dengan Media Lidi dalam Operasi Perkalian Matematika untuk Meningkatkan Karakter Kreatif dan Cinta Budaya Lokal Mahasiswa PGSD. Jurnal Seminar Nasional STKIP Siliwangi. Serang: Sekolah Pascasarjana UPI.

Simangunsong. S. W (2008): Matematika untuk SMP Kelas IX, (Jakarta: Erlangga, 2008), hlm. 67.

Sirate. S. F, (2012): Implementasi Etnomatematika dalam Pembelajaran Matematika pada jenjang Sekolah dasar, Sekolah Tinggi Keguruan Ilmu Pendidikan YPUP Jl. Andi Tonro Makasar, Email: fatimahsirate@yahoo.com

Sri Wardani/PPPG Matematika Yogyakarta, op. cit., hlm. 85 .

Tandililing, Edy. (2013): Pengembangan Pembelajaran Matematika Sekolah Dengan Pendekatan Etnomatematika Berbasis Budaya Lokal Sebagai Upaya Untuk Meningkatkan Kualitas Pembelajaran Matematika Di Sekolah, Makalah dipresentasikan dalam Seminar Nasional Matematika dan Pendidikan Matematika dengan tema "Penguatan Peran Matematika dan Pendidikan Matematika untuk Indonesia yang Lebih Baik" pada tanggal 9 November 2013 di Jurusan Pendidikan Matematika FMIPA UNY, P25.

Wahyuni. A. dkk (2013): Peran Etnomatematika dalam membangun karakter bangsa, Program Pascasarjana, Pendidikan Matematika UNY.

Widiastuti (2012): Upaya Meningkatkan Hasil Belajar Matematika Melaui Penggunaan Media Lidi Pada Penjumlahan Bilangan Bulat Siswa Kelas IV SD Negeri Banaran. Skripsi.Salatiga: Universitas Kristen Satya Wacana.

Lampiran IV Peraturan Menteri Pendidikan dan Kebudayaan Republik Indonesia Nomor 81a tahun 2013 tentang implementasi kurikulum pedoman umum pembelajaran

Infojambi.com, 28 Mei 2012. Mengenai budaya daerah Kerinci. 
Opini, Melemang Tradisi satu hari menjelang lebaran, 14 November 2014, diposkan oleh Dekha sajalah pukul 21.23.00

UU RI No. 14 Tahun 2005 tentang guru dan dosen.http//:Akhmad Sudrajat. wordpress.com 